The INL is a

U.S. Department of Energy

National Laboratory

operated by

Battelle Energy Alliance

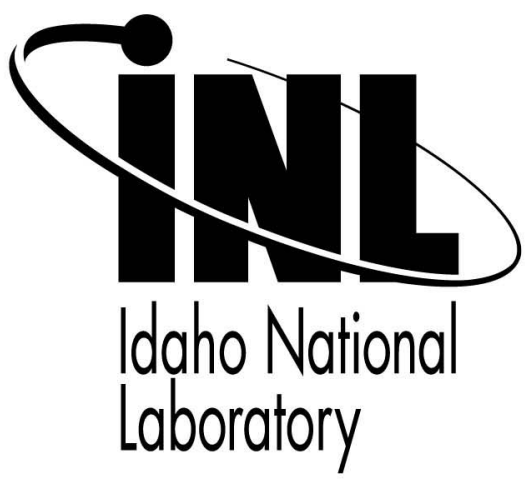

INL/CON-08-14630

PREPRINT

\title{
The Component Test Facility - A National User Facility for Testing of High Temperature Gas-Cooled Reactor (HTGR) Components and Systems
}

\section{HTR 2008: ASME Conference on High Temperature Reactor Technologies}

Vondell J. Balls

David S. Duncan

Stephanie L. Austad

September 2008

This is a preprint of a paper intended for publication in a journal or proceedings. Since changes may be made before publication, this preprint should not be cited or reproduced without permission of the author. This document was prepared as an account of work sponsored by an agency of the United States Government. Neither the United States Government nor any agency thereof, or any of their employees, makes any warranty, expressed or implied, or assumes any legal liability or responsibility for any third party's use, or the results of such use, of any information, apparatus, product or process disclosed in this report, or represents that its use by such third party would not infringe privately owned rights. The views expressed in this paper are not necessarily those of the United States Government or the sponsoring agency. 
HTR2008-58250

\section{THE COMPONENT TEST FACILITY - A NATIONAL USER FACILITY FOR TESTING OF HIGH TEMPERATURE GAS-COOLED REACTOR (HTGR) COMPONENTS AND SYSTEMS}

\author{
Vondell J. Balls \\ Next Generation Nuclear Plant Project \\ Idaho National Laboratory \\ Idaho Falls, Idaho, USA
}

\author{
David S. Duncan \\ Next Generation Nuclear Plant Project \\ Idaho National Laboratory \\ Idaho Falls, Idaho, USA
}

\author{
Stephanie L. Austad \\ Next Generation Nuclear Plant Project \\ Idaho National Laboratory \\ Idaho Falls, Idaho, USA
}

\begin{abstract}
The Next Generation Nuclear Plant (NGNP) and other High-Temperature Gas-cooled Reactor (HTGR) Projects require research, development, design, construction, and operation of a nuclear plant intended for both high-efficiency electricity production and high-temperature industrial applications, including hydrogen production. During the life cycle stages of an HTGR, plant systems, structures and components (SSCs) will be developed to support this reactor technology. To mitigate technical, schedule, and project risk associated with development of these SSCs, a large-scale test facility is required to support design verification and qualification prior to operational implementation.
\end{abstract}

As a full-scale helium test facility, the Component Test facility (CTF) will provide prototype testing and qualification of heat transfer system components (e.g., Intermediate Heat Exchanger, valves, hot gas ducts), reactor internals, and hydrogen generation processing. It will perform confirmation tests for large-scale effects, validate component performance requirements, perform transient effects tests, and provide production demonstration of hydrogen and other hightemperature applications.

Sponsored wholly or in part by the U.S. Department of Energy, the CTF will support NGNP and will also act as a National User Facility to support worldwide development of High-Temperature Gas-cooled Reactor technologies.

\section{INTRODUCTION}

Design and licensing ${ }^{1}$ of High-Temperature Gas-cooled Reactors in venues throughout the world requires significant investment in development of technologies that make the operation of these reactors safe and successful. In development of HTGR technology, much remains to be learned about the performance of materials from which critical reactor systems or components must be fabricated. For the NGNP, levels of readiness of needed technologies have been assessed. However, these levels vary significantly, based on the system or component being considered. This overall technology assessment process, referred to as Technology Development Roadmapping ${ }^{2}$ (TDRM), in part originated at NASA. It is used to assess, map, and plan the needed design development activities to take the particular component using Technology Readiness Levels ${ }^{3}$ (TRLs) from concept to a statesupporting normal operation. The overall TDRM process will determine what is needed to verify the safety and efficacy of the component through a series of scale test programs, up to and including tests at reactor temperatures, pressures, and flow rates. A facility that can provide engineering or large-scale capabilities for needed technology development is an outstanding need in the HTGR community.

This paper will present the current concept of the CTF and will propose how this facility will meet current and future needs related to testing of components and systems planned to support HTGR reactor technology. It will also propose how CTF will provide capability to allow demonstration of energy conversion and high-temperature application technologies that will move the United States away from its dependence on foreign oil.

This presentation will summarize the mission of CTF and its proposed design features. The following topics will be addressed and summarized for this new facility:

1. The Need for CTF

2. CTF Functions and SSCs Tested

3. CTF Site Layout

4. CTF Facility Layout

5. CTF Cost and Schedule. 


\section{THE NEED FOR CTF}

The 2005 Energy Policy Act ${ }^{4}$ (EPACT) charges the U.S. Department of Energy (DOE) and the Idaho National Laboratory (INL) with demonstration of the HTGR technology for the production of electricity and hydrogen by the year 2021 in a Next Generation Nuclear Plant (NGNP) demonstration. Meeting this commitment requires the INL to coordinate the efforts of several commercial and governmental entities over a wide range of technical areas. A significant portion of the technology development required to meet this commitment lies in the transfer of heat from the reactor to processes used in the NGNP for production of electricity and hydrogen. Ultimately, the technology will be used in a wider range of commercial applications following NGNP. This heat transfer occurs in the primary helium and secondary/tertiary fluid flow loops. In NGNP and in the early commercial applications of HTGR technology, fluids in these loops will be gaseous; e.g., pure helium, a mixture of helium and nitrogen, or other gases such as $\mathrm{CO}_{2}$. Current efforts for development of the technologies supporting design, construction, operation, and maintenance of these loops are concentrated in test loops at laboratory and larger scales. There are few facilities worldwide, available or planned, which have the capacity to develop and test equipment at engineering or larger scale levels.

Development of this test facility has the following advantages:

- Facilitates the coordinating, consolidating, and leading the development of the heat transfer and transport technologies needed to advance the application of HTGR technology

- Ensures the availability of a test facility for NGNP development and future HTGR development (the limited capacity and availability of existing facilities, most of which are international, could adversely affect NGNP schedule).
- Improves the efficiency of technology development for NGNP and follow-on technologies.

- Provides a means for off-line troubleshooting of component and system problems and allows development of programs and processes to ultimately support a growing commercial HTGR fleet.

- Provides a long-term, U.S. based facility for continued development of advanced technologies to increase the capabilities and broaden the applications of the HTGR.

DOE support of this facility would demonstrate full commitment to development of HTGR well before NGNP is scheduled for operation. This commitment will also support achieving industry participation in the Public-Private Partnership, central to success of the NGNP project.

\section{Current and Planned Test Facilities}

Before a new facility can be considered, existing test alternatives must be examined. Table 1 summarizes the capacities and status of existing high temperature gas loop testing facilities. A thorough review revealed the only engineering or large-scale capability in the German $10 \mathrm{MWt}$ EVA II loop, which is no longer in operation. The remainder of the facilities world-wide have much smaller capacities (i.e., laboratory and pilot scale) designed for special purpose testing. In planning for a CTF Helium test loop, desirable capacity is anticipated between $15 \mathrm{MWt}$ and $50 \mathrm{MWt}$ (with the higher capacity needed for demonstration of hydrogen and other high temperature heat applications), and as such will represent a significant upgrade in worldwide high-temperature gas loop testing capacity. 
Table 1. Summary of World-wide Existing and Planned Fluid Flow Test Facilities ${ }^{5}$

\begin{tabular}{|c|c|c|c|c|c|c|c|}
\hline Facility & Country & $\begin{array}{l}\text { Heating } \\
\text { Power, } \\
\text { MW } \\
\end{array}$ & $\begin{array}{c}\text { Flow } \\
\text { Rate, kg/ } \\
\text { sec } \\
\end{array}$ & $\begin{array}{c}\text { Pressure, } \\
\text { MPa }\end{array}$ & $\begin{array}{l}\text { Tmax, } \\
\text { Deg C }\end{array}$ & $\begin{array}{l}\text { Availability/ } \\
\text { Applicability }\end{array}$ & Comment \\
\hline $\begin{array}{l}\text { EVO } \\
\text { (Turbine) }\end{array}$ & Germany & 120 & 80 & 3 & 750 & Dismantled. & \\
\hline $\begin{array}{l}\text { HHV } \\
\text { (Turbine) }\end{array}$ & Germany & 100 & 200 & 5 & 850 & Dismantled. & \\
\hline $\begin{array}{l}\text { CT-1383 } \\
\text { (Main } \\
\text { Circulator) }\end{array}$ & $\begin{array}{l}\text { OKBM } \\
\text { (Russia) }\end{array}$ & $\begin{array}{c}\text { Not } \\
\text { available }\end{array}$ & 95 & 4.9 & 345 & $\begin{array}{l}\text { Dismantled/ } \\
\text { prolonged storage }\end{array}$ & \\
\hline KVK Loop & $\begin{array}{c}\text { AREVA } \\
\text { (Germany) }\end{array}$ & 10.0 & 4 & 4 & 950 & Dismantled. & $\begin{array}{l}\text { Operated for } 13,000 \text { hours, } \\
7,750 \text { at } 900^{\circ} \mathrm{C} 1981 \text { to } \\
1986 \text {. }\end{array}$ \\
\hline CT-1312 & $\begin{array}{l}\text { OKBM } \\
\text { (Russia) }\end{array}$ & 15 & 4 & 5 & 965 & $\begin{array}{c}\text { Dismantled/ } \\
\text { prolonged storage. }\end{array}$ & $\begin{array}{l}\text { Test of IHX and Steam } \\
\text { Generators }\end{array}$ \\
\hline HENDEL & $\begin{array}{l}\text { JAEA } \\
\text { (Japan) }\end{array}$ & 10 & 4 & 4 & 950 & Dismantled. & \\
\hline $\begin{array}{l}\text { HTF - } \\
\text { HTTU }\end{array}$ & $\begin{array}{l}\text { Pelindaba } \\
\text { (South Aftrica) }\end{array}$ & 0.5 & 0.5 & 10 & 1600 & $\begin{array}{l}\text { Unavailable until } \\
2012 .\end{array}$ & \\
\hline $\begin{array}{l}\text { HTF - } \\
\text { HPTU }\end{array}$ & South Africa & 0.1 & 2.8 & 5 & 35 & Not applicable. & Test fluid is nitrogen. \\
\hline $\begin{array}{l}\text { HELITE } \\
\text { Loop }\end{array}$ & $\begin{array}{c}\text { CEA } \\
\text { Cadarache } \\
\text { (France) }\end{array}$ & 1.2 & 0.4 & 8 & 950 & See comment. & $\begin{array}{l}\text { Design is complete; project } \\
\text { is on hold awaiting funding }\end{array}$ \\
\hline HELOKA & $\begin{array}{c}\text { FZK, } \\
\text { Karlsruhe } \\
\text { (Germany) }\end{array}$ & 3 to 8 & 1.8 to 5.5 & 10 & 700 & See comment. & $\begin{array}{l}\text { In development, operational } \\
\text { in } 2009 .\end{array}$ \\
\hline AECL- SNL & $\begin{array}{l}\text { United } \\
\text { States }\end{array}$ & 0.5 to 1 & $\begin{array}{c}\text { Not } \\
\text { available }\end{array}$ & $\begin{array}{c}\text { Not } \\
\text { available }\end{array}$ & $\begin{array}{c}\text { Not } \\
\text { available }\end{array}$ & See Comments & $\begin{array}{l}\text { Configured for Brayton } \\
\text { cycle critical } \mathrm{CO}_{2} \text { fast gas } \\
\text { reactor systems. Could be } \\
\text { retrofit for helium gas- } \\
\text { cooled thermal reactor work }\end{array}$ \\
\hline & \multicolumn{2}{|l|}{ Decommissioned } & \multicolumn{3}{|c|}{ Operational } & \multicolumn{2}{|c|}{ Planned or in Construction } \\
\hline
\end{tabular}

For reference, the NGNP power may be as high as 500 to $600 \mathrm{MWt}$ with primary flow rates of $\sim 160 \mathrm{~kg} / \mathrm{sec}$ to $\sim 280 \mathrm{~kg} / \mathrm{sec}$, maximum outlet temperature of $950^{\circ} \mathrm{C}$, and minimum inlet temperature of $350^{\circ} \mathrm{C}$. The current judgment is that the CTF should operate at least one test loop capable of $15 \mathrm{MWt}$ to $50 \mathrm{MWt}$, with gas flow rates of $10 \mathrm{~kg} / \mathrm{sec}$ to $20 \mathrm{~kg} / \mathrm{sec}$, and at temperatures that bound those for NGNP. This would permit engineering scale testing of the major components (e.g., IHX modules or scale models) before their installation in NGNP, as well as engineering scale demonstration of NHI hydrogen process modules, (e.g., sulfuriodine modules) prior to their design down-select for inclusion with the reactor design.

\section{CTF Testing Capabilities Needed for the DOE Nuclear Hydrogen Initiative}

The NGNP Project will rely heavily on engineering scale testing and demonstration of the hydrogen process in the CTF to prove the technical capabilities and reliability of the process before installation in the NGNP. CTF is currently expected to be available for testing in FY 2014, which will support timely selection of a hydrogen process for its inclusion in the NGNP design and licensing activity. CTF's design will include the configuration required to accommodate testing any of the hydrogen processes under consideration at a commercial scale.

Hydrogen process testing in the CTF will provide timely and necessary data required for down selection of the best technology for hydrogen production using an HTGR heat 
source. For example, establishing hazards and transient operating conditions will support development of bounding interface conditions to be used in design and licensing of the nuclear heat supply system.

The CTF is needed for this hydrogen process design demonstration activity because within the United States, only limited ability exists to test high-temperature $\left(>700^{\circ} \mathrm{C}\right)$ labscale heat exchangers. Ohio State University is constructing a bench-top helium closed-loop test apparatus that will allow testing of small $(\sim 1 \mathrm{~kW})$ heat exchangers beginning in early 2008. Plans exist for a lab-scale single-effects heat exchanger testing laboratory at an Idaho State University facility, adjacent to the Idaho National Laboratory. This facility will perform room temperature pressure-drop testing, static helium high-pressure leak testing at-temperature, hightemperature air-to-air heat transfer flow experiments, thermal cycling experiments, and other such tests. If funded, the single-effects laboratory would be ready for use by October 2008. Also, the University of Nevada Las Vegas, under their High-Temperature Heat Exchanger Project, has developed capabilities to test simple heat exchanger configurations under scaled fluid conditions.

With these limited existing or planned facilities to support NHI, construction and qualification of CTF and a large hightemperature helium loop facility becomes essential to support the design of the NGNP and HTGR heat transport loops, which will connect a high-temperature nuclear reactor heat source to a hydrogen production plant. The CTF would provide a large-scale helium test loop, capable of collecting data needed to qualify and optimize engineering-scale heat exchanger designs and other key components' durability and reliability, previously unavailable prior to this larger-scale deployment.

A large-scale helium test loop facility is also needed to properly evaluate the High-Temperature Electrolysis process as an alternative hydrogen process design. This process would split high-temperature steam into hydrogen and oxygen. This process must have a heat source from $800^{\circ}$ to $900^{\circ} \mathrm{C}$ to take the initial reagent water from its $25^{\circ} \mathrm{C}$ inlet condition to the HTE cell temperature of 830 to $880^{\circ} \mathrm{C}$. Depending on the amount of heat recuperation from the hydrogen and oxygen streams, steam generation and superheating consumes about $15-20 \%$ of the total energy needed in the hydrogen production process. The remainder of the energy is supplied to hydrogen production as electricity. Current estimates may indicate a required capacity of up to $50 \mathrm{MW}$ th to support a complete electrolysis test program.

\section{CTF FUNCTIONS AND COMPONENTS TESTED}

Pre-conceptual planning activities identified a large array of testing functions to support the NGNP Project and related initiatives. Currently, these functions include:
- Testing and qualification of high-temperature gas loop systems, components and equipment (e.g., Circulators, Intermediate and Tertiary Heat Exchangers, Piping, Isolation Valves)

- Control and Instrumentation development and qualification, (e.g., reliability, calibration, response, stability, and transient response)

- Verification and Validation (V\&V) of methods/codes to support licensing and future commercial applications (Thermal, Hydraulic, Transients, etc...)

- Heat transfer component development and fluid testing (e.g., shell, tube, and compact heat exchangers, sulfuric acid decomposers)

- $\quad$ Materials performance, (e.g., metals and ceramics)

- Mock-up for high-temperature heat applications testing and research (e.g., prior to installation into the NGNP)

- $\quad$ Fluid inventory and quality control systems

- Control room human factors

- Operations procedure development and qualification training (e.g., for NGNP and for future commercial plants)

- Operational problem/trouble shooting (e.g. for the NGNP prior to Hot system repair/modifications and to support future commercial applications)

- High-temperature applications, mockup engineering scale testing and qualifications, maintenance/repair program and process development

- Component replacement program and process development.

These functions are planned to be available for all HTGR critical SSC's. The current list of components to be tested includes:

- Intermediate Heat Exchanger (IHX)

- Ducting and insulation

- $\quad$ Mixing chambers

- Steam generator

- High temperature valves

- Specific application high-temperature instrumentation

- Industrial hydrogen components

- Helium circulators

- Scaled reactor pressure vessel integration and reactor internals 
- Process Control Systems, including Helium Chemistry Control

- Coupled systems and components.

In addition to heat exchanger testing, establishing and operating the loop facility will provide needed information on managing and controlling heat loads, helium circulator technologies, high-temperature instrumentation, hightemperature valves and flow control devices, and materials performance. Such information is highly valued by the DOE Nuclear Hydrogen Initiative, and having this information prior to full-scale deployment will greatly enhance the reliability of the heat transport systems.

\section{CTF SITE LAYOUT}

As presented in previous sections, a portion of the site must be designed to support other activities such as NHI. To account for needed space and to provide for other potential uses of the CTF, Figure 1 below represents the site layout conceived to organize and address all considered functions. The site model identifies those buildings which currently could consume space on the CTF site. The CTF layout covers approximately 27 acres and is tentatively located at the Central Facilities Area at the INL.

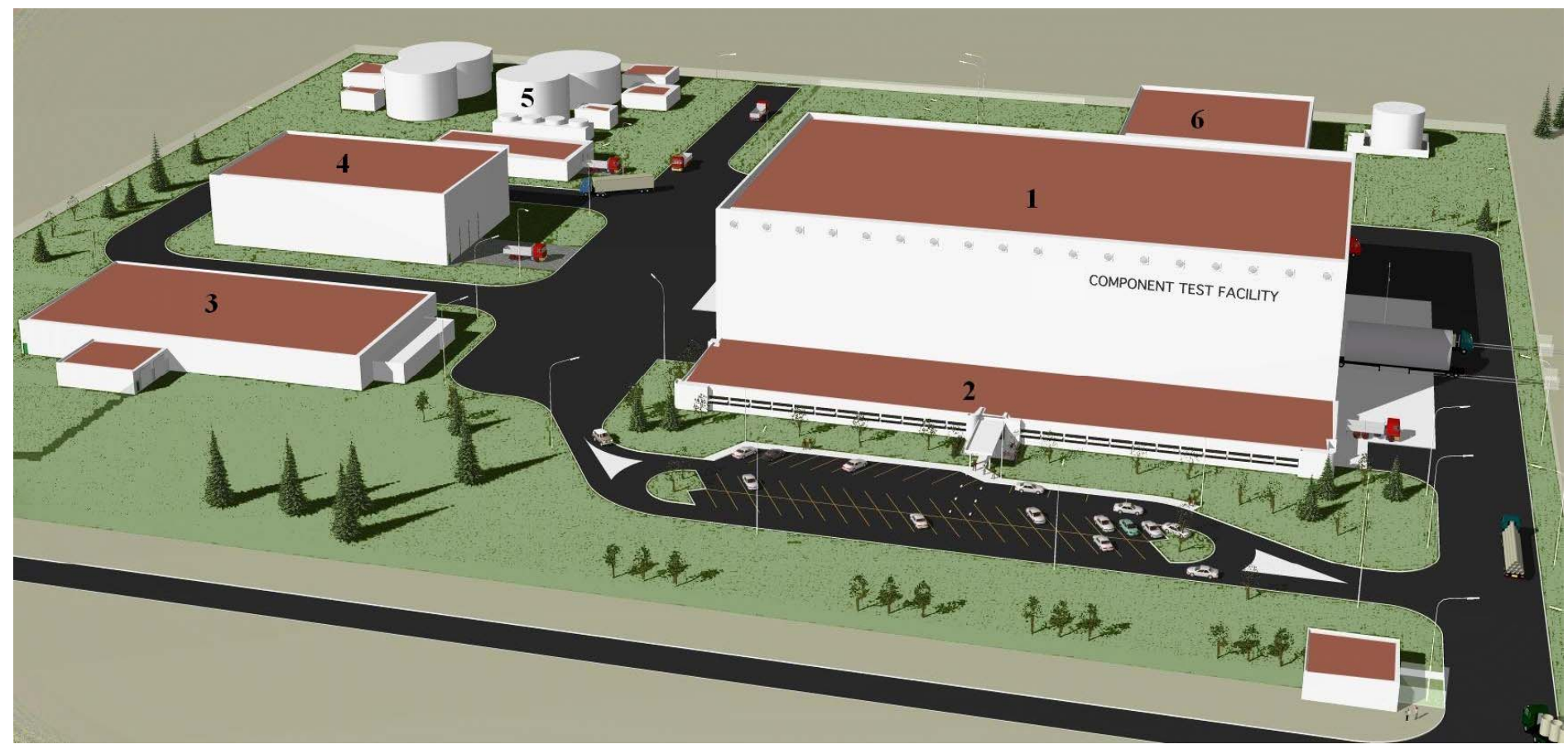

Figure 1. CTF Site Layout

The buildings numbered in figure 1 constitute the CTF site and are summarized in their function in the following list:

1. Component Test Facility High Bay- $400 \mathrm{ft} \times 220 \mathrm{ft}$ footprint, with dual 200-ton and 50-ton bridge cranes. The high bay will house up to four test development loops, a helium supply system, and space that can be reconfigured for pressure vessel fabrication.

2. CTF Administrative Support building- houses all rooms and offices for test control, data analysis, and test support, including analyticall laboratory space.

3. CTF Support Warehouse- provides storage and staging space for all planned test components and the equipment needed to support test activities.
4. Hydrogen Process Area- provides footprint only to organize yet un-finalized hydrogen process(es) designated and funded by NHI. Though shown as a building, it is currently estimated as an outdoor pad only. The intent of placement near CTF is to take advantage of nearby power capacity and a gaseous helium heat source.

5. Cooling Towers/Cooling Water Pumps and Water Storage- this area is configured for cooling towers and raw water storage tanks used in test loop cooling. Wells and associated pumps are positioned here to replenish the raw water storage tanks.

6. Generator Building/Switch yard- this building provides the footprint for the approximately $20 \mathrm{MW}$ of dieselgenerating capacity needed to allow for safe shutdown of the largest helium-cooled test loop(s) in a loss of power scenario. Directly to the left of this building is space for 
the switch yard, which handles and provides the significant power requirements for the CTF.

\section{CTF FACILITY LAYOUT}

The CTF building must be designed to accommodate the worst case required footprint for up to four test development loops and a helium supply system. Inside the high bay, the footprint must accommodate all test loops and have sufficient space to allow retrofit for pressure vessel fabrication and heat treatment. Currently, the high bay is dedicated to test loop activity. No area has been dedicated to pressure vessel fabrication and heat treatment.

The administrative support building contains office and lab space to support personnel conducting the required experiments. It also includes loop control rooms, maintenance and calibration labs, conference rooms, lunch room, I\&C development lab, machine shop, and other support space.

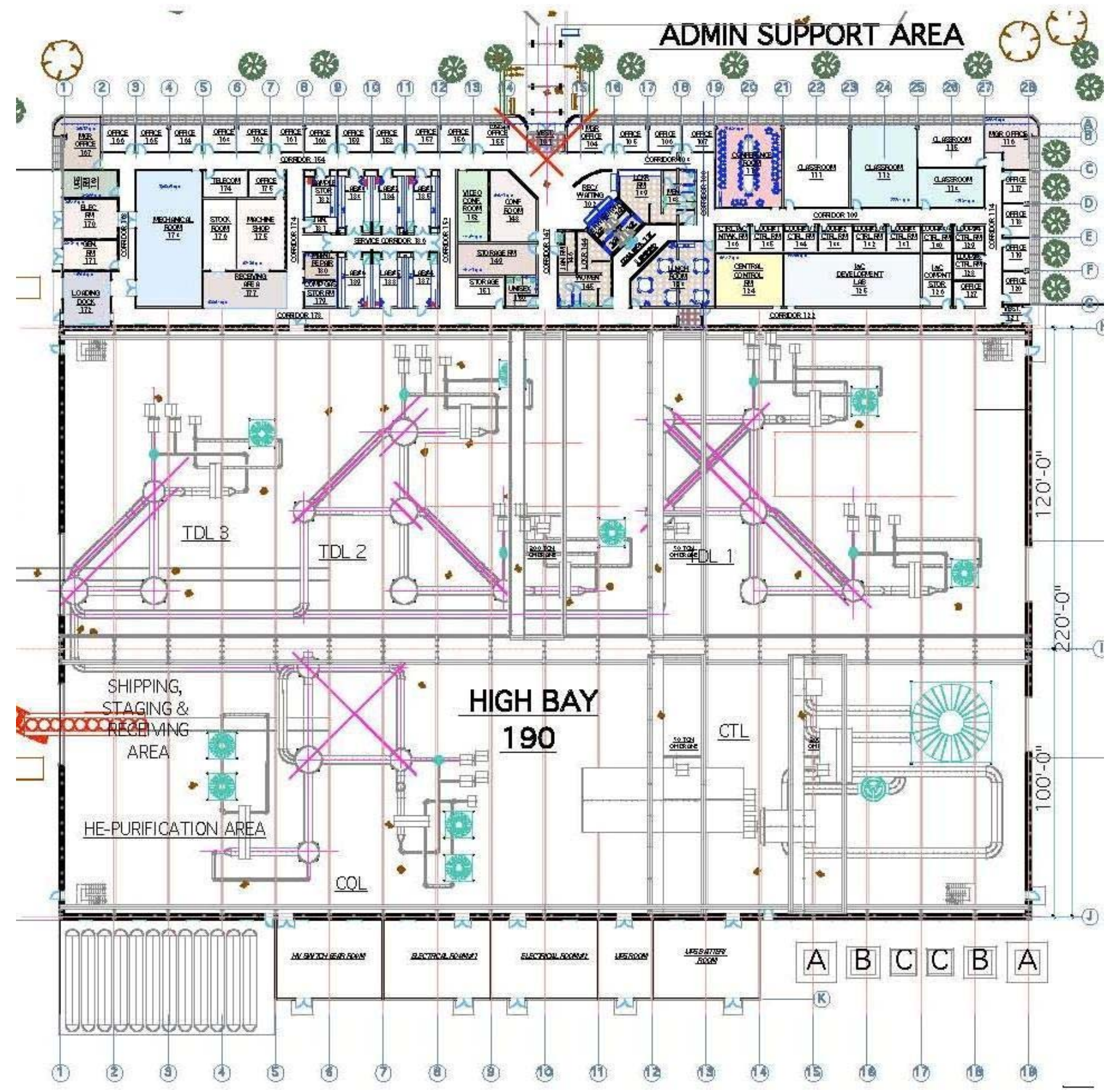

Figure 2. CTF Facility Floor Plan with Administrative Support Building 


\section{COST AND SCHEDULE}

Cost risk of the Component Test Facility project is dictated, in part, by the DOE 413.3A critical decision process. Other major contributors to risk include schedule and technology risk in design and fabrication of required test loops. Though the facility is a non-nuclear facility, NEPA issues also contribute to risk and affect both cost and schedule.

The cost range is based on the establishment of contingency at the $5 \%$ and $85 \%$ confidence levels. Planning estimates take into account the cost of the site, all buildings excluding the Hydrogen process building, and the four loops identified on the facility configuration drawings. Loop designs are based on limited pre-concept planning regarding the configuration of the loops. Completion of the TDRMs must be completed before a realistic estimate of loop cost can be established.

The development of the CTF is a key technology component of the NGNP development project with an early operational date required to ensure timely facility availability for NGNP design development. The current NGNP schedule shows initiation of the CTF Conceptual Design in October 2008. Identified as a Congressional Line item Construction project with completion milestones supporting the DOE O 413.3A Critical Decision process, the following is a high level schedule which accounts for delays due to critical decision approval and continuing resolution in the Federal Budget Cycle. Congressional funding has been requested to support the project commencing in the first quarter of FY 2010.

1. Conceptual Design Complete - 3Q FY09

2. CD-1 Approved (To Commence Preliminary Design) $-4 \mathrm{Q}$ FY09

3. Engineering/Procurement/Construction (EPC) Contract Placed - 1Q FY10

4. Preliminary Design Complete - 3Q FY10

5. CD-2/3A Approved (To commence final design and site preparation) - 4Q FY10

6. Final Design Complete/ Commence Site Prep/ Long Lead procurement - 3Q FY11.

7. CD-3 Approved (To commence Construction) - 4Q FY11

8. Commence Construction - 1Q FY12

9. Complete Construction -4Q FY13

10. Commence Start-up activities- 1Q FY14

11. Complete Start- up activities - 2Q FY14

12. CD- 4 Approved (COMMENCE Normal Operations) 3Q FY14

\section{CONCLUSION}

The CTF is essential to support design development of the NGNP and to act as a national user facility for development of HTGR technologies. The CTF is sized to advance components to successive technology readiness levels, as high as TRL 8, by completing the following types of tests for critical SSCs:

1. Confirmation tests for large-scale effects

2. Confirmation tests to verify heat transfer performance

3. Transient effects tests

4. Hydrogen production demonstrations for candidate hydrogen production technologies.

With these critical testing capabilities in a facility at power capacities in excess of $30 \mathrm{MWt}$, the CTF fills significant gaps in advancing the technology readiness of each critical SSC in the NGNP Project and other future HTGR projects. Also sponsored by the U.S. Department of Energy as a national user facility, the CTF is positioned to become a critical asset in the safe development and operation of all future High-Temperature Gas Reactors.

\section{ACKNOWLEDGMENTS}

The authors would like to acknowledge the support of the U.S. Department of Energy, Gas Reactor Deployment division of the Office of Nuclear Energy, NE-33, for their authorization and support of this work.

This manuscript has been authored by Battelle Energy Alliance, LLC under Contract No. DE-AC07-05ID14517 with the U.S. Department of Energy. The United States Government retains and the publisher, by accepting the article for publication, acknowledges that the United States Government retains a nonexclusive, paid-up, irrevocable, world-wide license to publish or reproduce the published form of this manuscript, or allow others to do so, for United States Government purposes.

\section{REFERENCES}

1. U.S. Nuclear Regulatory Commission, Code of Federal Regulations, Title 10, Part 52, "Licenses, Certifications, and Approvals for Nuclear Power Plants", January 2008.

2. Collins, J.W., 2008, "Roadmapping - A Systematic Approach to Overcoming NGNP Challenges", ASME Paper HTR2008-58221.

3. INL/EXT-08-14251, "Technology Readiness Plan", Idaho National Laboratory, June 2008.

4. Energy Policy Act of 2005 (EPAct; H.R. 6)

5. INL/MIS-08-14156(PLN-2763), "High level Requirements, High-Temperature Gas Reactor Component Test Facility", April 2008. 